\title{
THE FIRM AS A CONTRACT
}

\author{
M. Georgiev* \\ Economics Department, Agricultural University, Plovdiv, Bulgaria
}

\begin{abstract}
This study aims to clarify the firm in neo-institutional context. The firm is a particularly dynamic, constantly evolving process and an organizational structure. The firm is a symbiosis of entities, internal and external regulations, market and non-market mechanisms and relations, legal and economic conditions and effects. In the legal aspect, it is the sum of relationships developing inside and outside the scope of the organization legal process through which the property is managed. Economically, it is an organization created to profit from the production optimum. In the neo-institutional context, it is an abstract mechanism to control processes - on the one hand legal, economic, social and other administrative, marketing and arbitration - Contract processes. These companies have resources to create a balance between the costs behavioral resources for speed and security. The assessment of such corporate efficiency is based on transaction costs.
\end{abstract}

Key words Neo-institutional Economics, Contract, Transaction costs

\section{INTRODUCTION \\ STANDARD CONCEPTS REGARDING THE FIRM AND THE CONTRACT}

Legally speaking, the term "firm" is the name under which the trader performs his/her activities. However, there is a legal entity behind the firm - the trader. The firm is a subjective right, property of the trader and through it the latter identifies his/her activity. The trader is the person who, by means of the company, establishes certain relations, specific legal and economic - speculative goals. In a broader sense, we can assume that the firm is the legal structure that is used to manage property by separating it from the certain direct ownership carriers ${ }^{1}$. Then, the firm is an abstract legal form that is used to divide or unite certain legal relations depending on the interests. The firm is also a contract.

Within the meaning of the legal theory, the contract serves as the grounds on which the legal relations can be manifested. The latter is an agreement between parties for the purpose of establishing, changing or terminating a legal relation between them ${ }^{2}$. Going back to the firm, it is obvious that the firm is established, terminated or altered by virtue of formal,

\footnotetext{
${ }^{1}$ The survey makes it clear that with certain legal forms of traders (Sole traders and non-capitalized companies) the ownership and the management may merge.

${ }^{2}$ See Law on obligations and contracts regarding the legal definition (Bulgaria)
}

multi-lateral and concession contracts. The firm contract is both inside and outside the firm relations. The latter is where paid labour is. The latter can also be seen as a framework of the development of relations with external subjects concerning the firm property - the commercial enterprise.

In the classic and neo-classic economic context, the firm is a union of individuals established to pursue certain economic interests. Practically speaking, the union itself can be regarded as an individual economic subject. The classic theory says a lot on the issue of how these interests are distributed along the internal axis of the organization but the individual rationality and the motives of the individuals remain hidden. It is assumed that they are rational and have organizational unity regarding the objectives. In a certain way, the firm is like a "black box" transforming a number of relations into outgoing uniform stable states. The classic economic theory defines the firm as a basic way of generating revenue by means of: -economic behavior reaching its optimum state - in the knowledge about the exact correlations and the options to exchange the resources, the

\footnotetext{
${ }^{*}$ Correspondence to: Minko Georgiev, Economics department, Agricultural University - Plovdiv, 12 "Mendeleev"str., 4000 Plovdiv, Bulgaria, tel.032 /654 402,e-mail: mm72gg@gbg.bg
} 
structure of the products and the structure of the production;

-the economic relations connected with the definition of the market relations, on the sellerconsumer plane.

In the classic economic science, the contract is identified with the exchange of things, goods and services. This type of contract is rarely qualified. However, it is characterized as a momentous and actually performed activity related to the rearrangement, both in time and space, of the economic benefits and is also said to be indisputable regarding the effect of the contractual implementation. The subjects are always satisfied with the exchange, which means that the relations cease the moment when the exchange is implemented. The nonimplemented exchange shall not be discussed, although it plays an important role in the legal and economic turnover, especially when it is related to the firm.

The legal and economic theory focuses on the firm and the contract in a different way. In the first case, the meaning is to be found in the development of the rights and the obligations and the relationship-related equality and consequences of the illegal change in the behaviour of the subjects inside the firm and the firm as a separate entity - the nonimplementation of the contract. The economic theory is searching for meaning in this behaviour based on rationality, by measuring it in terms of money.

Coase (7) states that the legal and economic outlook does not lead to consensus regarding the form of the control over the property and labour. The author (in the same study) launches a new approach for analyzing firms as an economic organization integrating market and non-market relations.

\section{NEO-INSTITUTIONAL APPROACH - $N I E^{3}$}

The legal and economic (classic-type) analyses of the firm allow us to go to a higher level by establishing a new research approach - (NIE). NIE is where objectivism meets the rationality of the neo-classic economic paradigm and the subjective patterns of the Austrian economic school that have united in order to serve more practical and less abstract objectives. NIE offers a new scientific concept, integrating economy, organization and law (32). NIE is a peculiar interdisciplinary "update" of the entire economy (20). NIE unites the knowledge of

\footnotetext{
${ }^{3}$ NIA - Neo or New institutional economic (NIE - New Institutional Economics) - theoretical trend in economics, whose founder is said to be Oliver Williamson
}

firms as economic and legal subjects and their subjective internal and external relations.

The neo-institutional approach is viewed as an event within the scope of the modern economy, owing to the answers it gives to the questions posed by the theory: the process meaning of the organization and its existence in the form of a common financial and administrative unit; simultaneously functioning structure taking advantage of the multi-subjectivity and monosubjectivity; the role of the transaction costs within its doctrine; the place and the role of the rules and their formal, informal, short-term and long-term trajectories; including the market and why in the surrounding economic environment it is sometimes "deprived" of its dominant role; the dependence of social development and the economic growth from the perspective of the incentives related to the reorganization of the rules and the functioning of the organizations (12).

NIE clarifies the following: what necessitates and what results from the asymmetrical movement and the incompleteness of information; the economic aspects of the subjective (property) rights; the concept of collective actions (6) and their interdependence on technology and technological effectiveness.

This approach is used to describe most accurately the determinants related to: the institutions and their evolution in time as well as the assessment of the effect on the economic results mediated by and despite the effectiveness of the distribution of resources (19).

One of the key elements of this theory is the possibility to analyze abstractions, multi-layer and dual social concepts by reviewing:

-the objectivism and subjectivism of the economic, legal and organizational theory;

-the individuality and collectivity of the structure of the organization and its activities; -the unity between the internal and external organizational and process frameworks that determine joint effects;

-the willingness of the society to gain profits through the simultaneous division and unification of resources, which is expressed in the distribution and the integration of subjective rights;

-the coexistence and sometimes merging of the technological effectiveness and sociality;

-the contradiction in the effects of each individual action related to the sporadic inability to make a difference between the positive and negative social effects.

The approach can be regarded as an opportunity to find synergic solutions uniting 
the society by means of its individual economic agents - the firms.

\section{THE PLACE OF THE FIRM WITHIN NIE}

Coase (7), referring to Kaldor (17, p.123), explains that the movement of information is crucial for the firms as market subjects. The author also looks at the possibilities for the existence of a market when there are no firms and a market where anything happens within one single firm. In each firm, owing to the need of incessant signing of contracts with third parties and performing internal exchanges, a huge amount of data is to be processed. The need to know the environment and manage the resources requires specialization when conducting the economic activities. Coase (the same source) states that specialization puts pressure on the system of coordination and, as a result, on the prices that the organization works with. He asks the question: will there be any firms if the concept of self-regulation of markets works? In certain cases, firms give greater opportunities for profit through the internal organizational control of the utmost expenses. In other cases, it is more profitable to look for ways to "transfer" them outside the scope of the firm. All of this defines the firm as a basic tool of the economic organization.

The institutional theory regards the firm as a sum total of will and individual economic interest expressed in the subjective rights related to the management as well as the profits and the strive for profits. Because of the economic interest, the rights are called and analyzed the same way as the property rights ${ }^{4}$. Finally, the firm can be reduced to a sum total of residual rights - the right to take a decision and the right to residual income (13). However, property rights are those opportunities that determine the individual human behaviour regarding the property. The latter undoubtedly defines them as rules. The firm is a system for coordination of the legal and economic behaviour, with individual rights regarding the respective property. Within the firm, the organization has been established and subjected to collective actions as well (21), thus determining its position within the society, by means of the in-house and external market effects (8); (9). Then, the company is "something" that guides the choices resulting from the individual and collective possibilities to control the resources.

The modern firm is a peculiar form of interaction of the public matrix through the

\footnotetext{
${ }^{4}$ There is dualism in the economic theory when viewing the "property rights" as a "sum total of rights".
}

division of labour (25). There is a reason why Sklyarova (4) defines it as a mechanism setting the common actions used to specify the rights on a micro level. It is a way of manifesting consistency, hierarchy and the subordination of technology and also that part of the organization taken by non-production relations. This is the feature that determines it as a way of combining individual and collective will within the scope of legal acts that are internal and external for the organization (2). The firm is at the same time the core of the economic integration and also a means of exercising public control through the economic and legal division and allocation. The firm is an organization used to look for new opportunities in order to capitalize the advantages resulting from the control over the dissemination of information (5); (26), economize behavioral characteristics and also influence the rules - the institutions (20). It is a framework in which, just like in the contract, there are target filters for the information, which allows the latter to be used as a resource.

The firm itself consists of coordinated processes and rules. They evolve owing to the need to subject the collective will through the individual one, thus obtaining a higher value for each individual. At the same time, along with the development of the personal rights, the firm needs to be defended by means of restricting the validity of the foreign subjective rights. The firm is a way of restricting and protecting from this intrusion into one's own sphere. Owing to the vertical integration of the social relations, it is a way of protecting the individual and the organization by means of the effect that it may have on the contractual implementation. This feature has its price.

The firm's potential is a union of individual and collective internal knowledge expressed as the common potential of the economic agent to evolve. Due to the possession of specific knowledge or information, the ability to take risks, the entrepreneurial talent and the ability to negotiate and others, the individual has a certain place both inside and outside the organizational structure. This dichotomy often places the individual inside and outside the firm's organization as a party that conducts or ensures the implementation. The central arbitrator or agent is given a key role by concluding contracts as a representative or arbitrating the implementation within the scope of the firm's relations. $\mathrm{He} / \mathrm{she}$ is the figure that the economic subjects - firms use to defend their own interests, including in case of conflicts (1). This definition of the firm "blurs" 
its boundaries, just like the boundaries of the contracts.

The company is a union of internal and external subjects, internal and external will, internal and external rules (30). The modern firm is a contract (see 3, p. 38 for the concept) constituted by subcontracts or a networks of contracts (16).

The firm is a process and time framework extending outside the scope of the standard of the classic organization and within its doctrine the division and the integration can be viewed as an economic resource. Finally, NIE defines the firm as a contract that is:

- a control measuring mechanism that is used to control the prices and hence the social effects, some of which can be measured as transaction costs;

-a tool for achieving economic optimum (balances) based on the distribution of the property rights, which can be reduced to rights related to the management and rights related to the income;

-a method for controlling the behaviour through specialization of labour in which by means of assignment of power over certain resources the profit rate is increased;

-a method for affecting and controlling the coordination by manipulating the information flow, which eventually leads to certain economic advantages;

-a rule or a combination of behavioral rules used to achieve integration of the internal and external relations, which increases the possibility to influence other entities and structures, even such that can sanction the contractual non-implementation;

-a process consisting of various contractual and non-contractual relations - sub-processes (contracts).

\section{THE FIRM AS A COMBINATION OF CONTRACTS}

Hart (14) introduces the concept of comprehensiveness of the contract. In order to analyze the modern firm, the latter has to be "integrated" into the framework of the behavioral contract. The nature of the latter has been defined by Williamson. The modern firm is a symbiosis of the "partnership" between the standard negotiating and the institutionally imposed opposition, which can hardly even be defined as bargaining. Its scope encompasses: chicaning, manoeuvering ${ }^{5}$, which in the economic context is also known as outwitting, beating around the bush,

\footnotetext{
${ }^{5}$ The legal terms for tactic practices used in legal processes. According to the neo-institutional theory, they are a typical form of opportunism.
}

outsmarting (29). These trends are typical of subjects having big collective governing bodies and we need to point out that the modern firm structures often mirror the political situation.

The modern firm can be divided into two types: (a) homogenous organizations that have clear property and management, conducting specialized and mostly uniform activities and hence contracts that are clear in terms of shape, structure and framework; (b) organizations whose objectives change quickly and that have changeable behavioral and structural integrity, in which the hierarchy of the rules changes incessantly and so do the holders and the contractual relations.

The latter type - firms having a large share of cashless property are often a multitude of interwoven legal forms - holdings, consortia, mergers, acquisitions, which are used to exchange property shares and power (the rights) related to the management. Due to the principled openness of markets, nowadays there are firm entities that have merged on one level (as property) and have separated and even become opponents on another level. The "unspecified" property results in firm unions that have complex, multistage management taking the decisions, which is collective but sometimes its rationality is external to the certain contract framework. This determines firm strategies for growing rich that are different from the forms contained in the classic economic theory. In other words, such firms make profits by using complex contractual forms, some of which do not involve "adding" but are rather a combination of legal actions for "taking away" from the value of the firm property. We can give an example with firms that are divided or even liquidated owing to the establishment of a routine activity that requires unjustifiably high specialization of labour. This type of firms uses contract fragmenting as a way of creating new markets with monopolistic features.

Firms are used as a way of making profits fast by means of contract transformations supporting the "strengthening" of the legal situation which is said to be a market situation but with a strongly manifested non-market effect in the long term. These firms often conceal their activity through the contract framework of associations that do not have the right to gain profits. Owing to the growing need of incessantly increasing personal consumption, in contrast with the desire to reduce the prices of the products and the continuous increase in the prices of resources 
(24), where it is expected to have no market growth in the long term, the firm contract adopts the features of a cartel alliance. It is logical that some of the discussed contract unions are not typical agreements and are not based on equality.

For that reason, some of the modern firms are contracts:

-with provisionally deleted boundaries between the formal and informal organizational structures;

-in which there are sometimes successfully running mutually-exclusive processes of division and integration

Here comes the logical question of what basis can be used to outline certain boundaries of the firm structure.

\section{LEGAL FORMS AS "CARRIERS" OF THE FIRM CONTRACT}

"...there are many variables affecting the condition of the contractual relations when negotiating and signing contracts" (23, p. 150). In this firm and contract complexity there is a need to find a form of unification that can be used in the analysis. Here comes the legal theory. It has set the frameworks of the processes in view of achieving certain legal objectives. The studies related to the legal process have precisely and clearly defined the series of legal actions and the possibilities related to the need of defending rights. By means of legal proceedings, we can determine the actions to be taken in order to defend a certain subjective right, ensuring a protection against any potential non-execution of the process. The latter makes the firm contract measurable, based on the analytical foundation of "the life" of the procedural rights. Legal proceedings serve as an evaluation of the firm contract by means of framing the actions of the participants and in particular determining the level of their definiteness, specific nature and measurability. At the same time, they are a way of removing, or at least reducing part of the indefiniteness, which means that they increase the levels of measurability, definiteness and reduce the specific nature of the firm contract.

By means of legal proceedings, we can analyze the comprehensiveness of the firm contract, especially when evaluating the simultaneously running:

-market and non-market processes; -contractual and disputable processes.

Some of the issues related to the legal framework of the contract are discussed by (22).In addition to typical contracts, firm contracts evolve both in the administrative processes and the disputable proceedings court trials. This concept of the modern firm allows us to make measurements that can later be used in a comparative economic analysis.

We can draw the following conclusions: -the firm contract is a system of organization spreading outside the scope of the classic union, which is a sum total of internal and external processes united by the legal proceedings;

-the firm contract is the series of sometimes inseparable acts serving the contract, the administrative and court trials for the purpose of defending the interests of the economic subjects.

\section{NEO INSTITUTIONAL FIRM EFFECTIVENESS.}

Neo-institutional firm effectiveness means establishing the "price" of the optimal behaviour within a random contract framework. This means that the firm contract will be analyzed as an effect of the manifestation of property rights, which leads to certain positive and negative effects. The latter means that the balance or the optimum of the rights will be guaranteed by the long-term success of the economic subject. This evaluation is possible in case of a firm contract generating continuously dropping transaction costs.

There are two concepts for measuring transaction costs. In the first case there is a condition to divide the economy into sectors, one of which is the transaction sector, part of which are the transaction costs (27). This survey does not support this way of measuring and analyzing.

The other concept suggests that the transaction costs are the result of certain subjective actions under the contract (31). This approach views effectiveness as a consequence resulting only from the individual behaviour within the exchange or redistribution of rights. Transaction costs are part of the concept for defending subjective rights (15); (8); (11); (11). They are also the behavioural structure taking into account the irrationality of the last actions - the opportunism costs (29). There is also an option to structure discretely and then analyze each decision and action. This theoretical framework is aimed at achieving the optimum through the answers of the following questions:

1. What exactly is to be understood by the notion of safety and how is the latter to be measured and economized?

2. Where is the dividing line between the need to protect certain property and the actions that 
are said to be opportunistic and lead to losses measured by means of expenses?

Regarding the first question, it is important to determine the scale of the needed defence of a preliminarily specified result, sometimes specified - in the form of a resource. The "conflicts" related to the economic concepts for distribution of resources and the legal concept regarding the scope of the subjective rights are brought to the foreground. If the firm effectiveness is a social balance determined by the diffuse action of multiple rights, what is there to be done so that they will be in a state that will not require them to be defended, which will result in a low level of the costs?

Regarding the second question, we need to know that in each action there is a certain amount of irrationality. This question is related to the definition of the "exact" contract form and also to the factors affecting the contract coordination and the optimum costs. But, if it is possible to solve the problem of irrationality, we need to find solutions outside the scope of the justification of the benefit of each expense. The latter takes us back to solving Coase's theorem and the safety issues.

\section{CONCLUSION}

The modern firm is a multi-layer contract organization serving certain subjective purposes and social interests. Its outlines are blurred and in many cases there is rationality which is only visible within the frameworks of the different theories.

The firm contract is:

First: a legal, economic and organizational framework with blurred outlines, uniting various purposes, will and effects;

Second: a mechanism for theoretical and empirical analysis of non-production relations intended to find the answer to the question about the reason for the existence of cartel alliances;

Third: a possibility to reduce the economic insecurity by finding the right balance of the property rights which will lead to reducing the transaction costs.

\section{REFERENCES}

1. Аузан, М., Институциональная экономика, Под ред. А. А., Новая институциональная экономическая теория, Изд-во МГУ, с. 416, 2006.

2. Корпоративное право: Актуальные проблемы теории и практики, под общ. ред. В. А. Белова, Москва, Издательство Юрайт, Актуальные проблемы теории и практики, с. 678, ISBN 978-5-9916-009652009. 2009.
3. Коуз, Р., Фирма, рынок, право. Москва, Дело, с. 38, 1993.

4. Склярова, М. Е., Фирма как механизм управления коллективной собственностью в процессе спецификации прав собственности на микроуровне, Вестник НГУ. Серия: Сочиально-экономические науки, 2012, Т. 12. Вып. 3. с. 34-43, 2012.

5. Akerlof, G., The Market for Lemons: Qualitative Uncertainty and the Market Mechanism, Quarterly Journal of Economics, 84: 488-500, 1970.

6. Clague, C., P. Keefer, S. Knack and M. Olson, Institutions and Economic Development: Growth and Governance in Less-Developed and Post-Socialist Countries. The Johns Hopkins University Press: Baltimore, Maryland, 1997.

7. Coase, R., The Nature of the Firm. Economica 4, 1937

8. Coase, R., The problem of social cost. Journal of Law and Economics 3:1-44, 1961.

9. Dahlman, J., The problem of externality, Journal of Law and Economics, v. 22:141162, 1979.

10.Demsetz, H., 'Review: Oliver Hart, Firms, Contracts, and Financial Structure, Journal of Political Economy, (1998), 106: 446452, 1998

11.Demsetz, H., Towards a theory of property rights. American Economic Review 57: 347-359, 1967.

12.Harriss, J., J. Hunter and C. M. Lewis, The New Institutional Economics and Third World Development. Routledge: New York. 1995.

13. Hart, O. and J. Moore, Property rights and thenature of the firm. Journal of Political Economy 98:1119-1158, 1990.

14.Hart, O., Firms Contracts and Financial Structure, Oxford, Clarendon. 1995

15.Hicks, J., A Suggestion for Simplifying the Theory of Money, Economica 2: 1-19, 1935.

16.Jensen, M. and Meckling, W. H., Theory of the firm: managerial behavior, agency costs, and ownership structure" 1-77, 1976., http://papers.ssrn.com/abstract=94043, (Dawnload 28.07.2007)

17.Kaldor, N., 1934. "The Equilibrium of the Firm," The Economic Journal 44: 60-76. 1934.

18. Morten Hviid, Long-Term Contracts and Relations Contracts, University of Warwick, Department of Economics, pp.46- 72, 1999.

19.Nabli, M.K., and J.B. Nugent.,The New Institutional Economics and Its Applicability to Development World 
Development, Vol. 17, No. 19:1333-1347, 1989.

20.North, D., Institutions, Institutional Change and Economic Performance, Cambridge University Press, 1990.

21.Ostrom, E., Source An Agenda for the Study of Institutions, Public Choice, vol. 48, no. 1: 3-25, viewed SpringerLink, DOI 10.1007/BF00239556, 1986.

22.Posner, R., An Economic approach to legal procedure judicial administration, Journale of legal Studies 2, 1974.

23.Salanié, Bernard, The Economics of Contracts, London, MIT Press, 1997.

24.Shapiro, C., Attribute to Oliver Williamson: Antitrust Economics, Review California Management, V52, No2, Reprintseries The Regents of the University of California. 2010.

25.Stigler, G., The Devision of Lebour is Limited of Exstend of the Market, Journale of the Political Economy 59(3):185-193, 1951.

26.Stiglits, J., Freefall: America, Free Markets, and the Sinking of the World Economy, W. W. Norton \& Company, 2010.
27.Wallis, J., and D. North, Measurement Transaction Sector in American Economy, 1870-1970, In Engerman and Caman (eds.) Long-Terms Factor in American Economy Growth. Chicago: Chicago University Press: 95-148, 1986.

28. Williamson, O., Cost Economic: How It Works; Where It Is Headed, De Economist 146, No. 1:1-58, 1998.

29.Williamson, O., The economic institutions of capitalism: Firms, markets, relational contracting, New York, NY: Free Press. 1985

30.Williamson, O., The Mechanisms of Governance, Oxford: Oxford UniversityPress, p.58 1996.

31.Williamson, O., Transaction-cost economics: The governance of contractual relations. Journal of Law and Economics, 22(2):233-261. 1979.

32.Williamson, O., Why Law, Economics, and Organization? University of California, Berkeley, 2000., http://papers.ssrn.com/paper.taf?abstract_id $=255624,($ Download 2007). 